\title{
Study of lifetime of Platinum Modified Metal Oxides Electrodes
}

\author{
Lemeyonouin Aliou Guillaume POHAN ${ }^{1 *}$, Ollo KAMBIRÉ ${ }^{2}$, Mohamed BERTÉ ${ }^{3}$ and \\ Lassiné OUATTARA ${ }^{3}$
}
${ }^{1}$ UFR Sciences Biologiques, Université Peleforo Gon Coulibaly de Korhogo, BP 1328 Korhogo, Côte d'Ivoire.
${ }^{2}$ UFR Sciences et Technologies, Université de Man, BP 20 Man, Côte d'Ivoire.
${ }^{3}$ Laboratoire de Constitution et Réaction de la Matière, UFR SSMT, Université Félix Houphouët-Boigny de Cocody, Abidjan, 22 BP 582 Abidjan 22, Côte d'Ivoire.
*Corresponding author; E-mail: pohan.aliou@gmail.com

\begin{abstract}
$\mathrm{Pt}, \mathrm{IrO}_{2}, \mathrm{RuO}_{2}, \mathrm{Pt}-\mathrm{IrO}_{2}$ and $\mathrm{Pt}-\mathrm{RuO}_{2}$ electrodes have been shown to be effective in their application in various fields. However, it is necessary to study their long-term stability. So, our objective is to prepare them and study their lifetime using intensiostatic measurement. Then they were prepared at $400{ }^{\circ} \mathrm{C}$ on titanium plates used as a substrate. Physical measurements (scanning electron microscopy) of these anodes revealed that their surface are rough and porous structures. Lifetime study was carried out in $\mathrm{H}_{2} \mathrm{SO}_{4} 9 \mathrm{~N}$ and under a current density of $410 \mathrm{~mA} / \mathrm{cm}^{2}$. The long-term stability of Pt improved when coupled to $\mathrm{IrO}_{2}$ in contrast to $\mathrm{RuO}_{2}$. From this study, the performance of the electrode was found to increase in the order: $\mathrm{RuO}_{2}<\mathrm{Pt}-\mathrm{RuO}_{2}<\mathrm{Pt}<\mathrm{Pt}-\mathrm{IrO}_{2}<$ $\mathrm{IrO}_{2}$. For $\mathrm{RuO}_{2}$ and $\mathrm{IrO}_{2}$ pure electrodes, the deactivation would be due to the dissolution of precursors deposited on the titanium. For the Pt pure electrode, deactivation would be due to the detachment of platinum coating. The deactivation of the Pt-IrO${ }_{2}$ and $\mathrm{Pt}-\mathrm{RuO}_{2}$ electrode would be due, on the one hand to the platinum detachment from $\mathrm{IrO}_{2}$ or $\mathrm{RuO}_{2}$ and on the other hand to the metal oxides $\left(\mathrm{IrO}_{2}\right.$ or $\left.\mathrm{RuO}_{2}\right)$ dissolution.
\end{abstract}

(C) 2020 International Formulae Group. All rights reserved.

Keywords: Electrodes, platinum, metal oxides, lifetime.

\section{INTRODUCTION}

Electrochemistry is a multidisciplinary science. It is applied in various sectors such as energy production and / or storage, electrosynthesis, the corrosion phenomena study, analysis, wastewater treatment, chlorine and oxygen production (Liu et al., 2014; Datché et al., 2014; Kambire et al., 2015a; Maman et al.2017; Coulibaly et al., 2018). Today, this science has received great attention for the wastewater treatment (Olvera-Vargas et al., 2015; Huguenot et al., 2015; Pohan et al., 2013), due to the ineffectiveness of biological treatments in presence of refractory or recalcitrant molecules (Oller et al., 2011; Sawadogo et al., 2012 ; Ouedraogo et al., 2020).

For such a technique, the electrode material plays an important role. Thus, the platinum electrode $(\mathrm{Pt})$ is the ideal candidate due to its good electrical conductivity and also its resistance to corrosion (Kambire et al., 2015b). Besides its properties, platinum has efficiently been used in many fields such as, electronics, fuel cells, organic compound oxidation (Yi et al., 2011). However, its relatively high cost sometimes limits its use. It 
is therefore necessary to find alternatives to platinum.

In order to solve the problem of the high cost, some of the actual researches were focused on adding to platinum some with metallic adatoms such as tin $(\mathrm{Sn})$, ruthenium $(\mathrm{Ru})$ and lead $(\mathrm{Pb})$ (Gong and Zhao, 2019; Klein et al., 2019). Even if those adatoms added to platinum contribute to increase its electrocatalytic activity, they are known to present stability or life problems (KhalifehSoltani et al., 2020).

Since the DSA (dimensionally stable anode) electrodes discovery by Beer (Kambire et al., 2015b), a lot of research efforts were made on such kind of electrodes due to high electrocatalytic activity, high stability against anodic corrosion and also a very high mechanical stability (An et al., 2012). DSA electrodes are generally formed by a mixture of active and inert metal oxides. These metal oxides provide them high catalytic activity and higher life (Zhou et al., 2011). Thus, it appeared to us necessary to combine platinum to DSAs.

In prior investigation in our team, it has been shown that combining $50 \%$ molar ratio of Pt and metallic oxides led to obtain electrode with higher electrocatalytic activity, and higher kinetics for OER and CER (Oxygen and Chlorine Evolution Reactions) (Pohan et al., 2013a; Kambire et al. 2015b; Kambire et al., 2015c). But the lifetime studies for these electrodes does not exist by our knowledge.

In this work, we will prepare different electrodes (platinum $(\mathrm{Pt}$ ), ruthenium dioxide $\left(\mathrm{RuO}_{2}\right)$, iridium dioxide $\left(\mathrm{IrO}_{2}\right), \mathrm{Pt}-\mathrm{RuO}_{2}$ and $\mathrm{Pt}-\mathrm{IrO}_{2}$ ) thermally followed by their physically and electrochemical characterization. The lifetime studies of these electrodes was realized by intensiostatic measurement, under a high anodic current (current density of $410 \mathrm{~mA} / \mathrm{cm}^{2}$ ) and immersed in a very aggressive chemical medium (sulfuric acid $9 \mathrm{~N}$ ).

\section{MATERIALS AND METHODS Thermal preparation of electrodes}

Sandblasted titanium metal supports (or substrates) have been used in order to increase the roughness which improves the adhesion of the deposit to the titanium support. The surfaces were degreased and cleaned with isopropanol followed by rinsing with distilled water. On the surfaces of the pretreated electrodes precursors of $\mathrm{H}_{2} \mathrm{PtCl}_{6} \cdot 6 \mathrm{H}_{2} \mathrm{O}$ (Fluka, $\geq 37.50 \%$ ), $\mathrm{RuCl}_{3} \cdot \mathrm{xH}_{2} \mathrm{O}$ (Fluka, 99.98\%) and $\mathrm{H}_{2} \mathrm{IrCl}_{6} .6 \mathrm{H}_{2} \mathrm{O}$ (Fluka, 99.98\%) were applied by brushes. These precursors were diluted in isopropanol (Fluka, 99,9\%). The deposit solvent was evaporated in the oven at $80{ }^{\circ} \mathrm{C}$ for $10 \mathrm{~min}$. Then the deposit underwent thermolysis in the oven in $15 \mathrm{~min}$ at $400{ }^{\circ} \mathrm{C}$. Several layers of deposit were thus produced before being calcined in an oven at $400{ }^{\circ} \mathrm{C}$ for one hour. The deposit loading was about $5 \mathrm{~g} / \mathrm{m}^{2}$ on each titanium substrate (Kambire et al., 2015b).

\section{Characterization of the prepared electrodes}

High resolution images of the prepared electrodes surfaces were obtained by scanning electron microscopy (SEM, ZEISS, SUPRA 40VP). The electrochemical measurements were carried out using a conventional threeelectrode electrochemical cell known as the Piontelli assembly. The reference electrode, which is a saturated calomel electrode (SCE), is put in a capillary luggin, the end of which is placed very close above the working electrode (WE) in order to overcome the ohmic drop. The area of the counter electrode (spiral platinum wire as counter electrode (CE)) is at least one hundred times larger than that of the working electrode whose surface is $1 \mathrm{~cm}^{2}$. The working electrodes used are the prepared electrodes. The three electrodes are connected to an ECHOCHEMIE Autolab Potentiostat / galvanostat (PGSTAT 20) connected by interface to a computer (Kambire et al., 2015b).

\section{Electrode life studies}

In order to know the prepared electrodes lifetimes, aging tests were carried out in $9 \mathrm{~N}$ sulfuric acid under a current density of 410 $\mathrm{mA} / \mathrm{cm}^{2}$. In fact, during its use, the anode is subjected to very severe operating conditions originating from a high anode current and from the chemical aggressiveness of the medium. 
The anode will be considered deactivated if its potential reaches $10 \mathrm{~V} / \mathrm{SCE}$. The solution is constantly stirred to remove the gas bubbles formed on the working electrode surface. The presence of those gas bubbles would contribute to increasing the cell resistance. Two multimeters are used, one to impose exactly the desired current and the other to follow the potential evolution during the test. A generator is used to power the cell thus produced. All measurements were made at $25^{\circ} \mathrm{C}$.

\section{RESULTS}

\section{Characterization by scanning electron microscopy (SEM)}

Figure 1 shows the different deposits of $\mathrm{Pt}, \quad \mathrm{RuO}_{2}, \quad \mathrm{Pt}-\mathrm{RuO}_{2}, \quad \mathrm{IrO}_{2}, \quad \mathrm{Pt}-\mathrm{IrO}_{2}$ on sandblasted titanium. The micrograph of the pure platinum electrode $(\mathrm{Pt})$ has a smooth, compact and almost homogeneous surface. That of pure ruthenium dioxide $\left(\mathrm{RuO}_{2}\right)$ electrode shows rough surface with cracks and pores. The surface of the iridium dioxide $\left(\mathrm{IrO}_{2}\right)$ electrode shows overlapping layers of iridium dioxide, cracks and pores. The platinumruthenium dioxide $\left(\mathrm{Pt}-\mathrm{RuO}_{2}\right)$ coupled electrode has a compact surface, characteristic of platinum on its surface, and cracks, due to the $\mathrm{RuO}_{2}$ presence. The surface of the platinum-iridium oxide $\left(\mathrm{Pt}-\mathrm{IrO} \mathrm{I}_{2}\right)$ coupled electrode has almost the same characteristics as the Pt- $\mathrm{RuO}_{2}$ electrode. On this electrode the roughness and the cracks are more marked.

\section{Electrode life studies \\ Ir $\mathrm{O}_{2}$ electrode}

On the iridium oxide $\left(\mathrm{IrO}_{2}\right)$ electrode, the potential evolution recorded during the polarization time is presented in Figure 2a. In this figure, the potential is almost constant from 0 to 678 hours of polarization. From 678 hours to 1230 hours, there is a progressive increase in potential and after 1230 hours, it increases suddenly.

At points $\mathrm{A}, \mathrm{B}$ and $\mathrm{C}$ in Figure 2a, which correspond to the polarization times of 0,678 and 1421 hours, respectively, are associated with the voltammetric curves A, B and $C$ (Figure 2b). Curve $A$ shows the voltamogram of the freshly prepared iridium oxide electrode. This voltammetric curve has a high voltammetric charge with localized peaks at $0.7 \mathrm{~V}$ and $1 \mathrm{~V} / \mathrm{SCE}$ potentials. After 678 hours of polarization, curve $\mathrm{B}$ is recorded. An increase in the voltammetric charge is observed from curve A to curve B. From 678 hours (curve B) to 1421 hours (curve C), the voltammetric charge gradually decreases and becomes lower than that of the freshly prepared electrode. This observation shows the loss of the electrode electrochemical activity, after 1421 hours of polarization.

\section{Pt electrode}

The potential evolution versus the polarization time, on the platinum electrode, is shown in Figure 3a.

The potential hardly varies until 72 hours of polarization. Beyond that, the potential increases very quickly. Before polarization, a voltammetric curve of the platinum anode was recorded (Figure 3b, curve A). On this voltammogram, we have more or less significant voltammetric charges in places. The voltammetric curve recorded after the potential jump, shows a strong decrease in the voltammetric charge after 72 hours of polarization (Figure 3b, curve B). The electrode would be deactivated after 72 hours of polarization.

\section{Pt electrodes modified by $\mathrm{IrO}_{2}$}

On the Pt- $\mathrm{IrO}_{2}$ electrode, Figure $4 \mathrm{a}$ shows the potential evolution versus the polarization time. We have the potential which is almost constant from 0 to 306 hours (from A to B) of polarization, followed by a slight increase in the potential from 306 to 400 hours of polarization. After 790 hours, the potential gradually increases to lead to a potential jump after 1200 hours. At 1369 hours of polarization (point $\mathrm{D}$ ), the potential recorded is $12 \mathrm{~V}$. The electrode would therefore be deactivated.

Figure $4 \mathrm{~b}$ presents the voltammograms recorded at A, B, C and D at 0, 306, 790 and 1396 hours of polarization, respectively. The curve A present the characteristics of the platinum anode and of the iridium anode. This shows the presence of both elements (platinum and iridium oxide) on the surface of the $\mathrm{Pt}-\mathrm{IrO}_{2}$ electrode ( $50 \%$ by mol of each element). After 790 hours, curve $\mathrm{C}$ has a higher voltammetric 
charge than curve $\mathrm{B}$, and this curve is similar to $\mathrm{IrO}_{2}$. The charge of the electrode increases as observed with pure $\mathrm{IrO}_{2}$. There is therefore an activation of the iridium oxide after the departure of the surface platinum. At 1369 hours (curve D), the voltammetric charge begins to decrease and there is an increase in the cathode current, which would reflect the deactivation of the electrode.

\section{$\mathrm{RuO}_{2}$ electrode}

The curve giving the potential evolution versus the polarization time, on $\mathrm{RuO}_{2}$ is represented in Figure 5a. In this figure, the potential is constant from 0 to 2 hours of polarization. It increases slowly after 2 hours until 5 hours, followed by a sudden potential jump after 5 hours of polarization.

To follow the evolution of the electrode $\left(\mathrm{RuO}_{2}\right)$ surface, its voltammetric charge was determined by performing voltammetric measurements at different polarization times during the lifetime test (Figure 5b). In this figure, curve A corresponds to the voltammogram recorded before the polarization and curve $\mathrm{B}$, after the potential jump. On curve $A$, the redox transitions peaks are not very visible and the ohmic resistance seems strong. Curve B has almost the same aspects as curve $\mathrm{A}$, with a reduction in the voltammetric charge.

\section{Pt electrodes modified by $\mathrm{RuO}_{2}$}

On Pt-RuO 2 , the potential is constant from 0 to 23 hours, then gradually increases from $23 \mathrm{~h}$ to 25 hours. From 25 to 26 hours, the potential does not vary and increases rapidly after 26 hours (Figure 6a). The potential jump that occurs after 26 hours would indicate deactivation of the electrode.

The electrode deactivation would not lead to the complete the deposit departure on the support (Figure 6b). Curve B (29 h), recorded after the potential jump still shows the presence of ruthenium oxide on the support and also some traces of platinum.
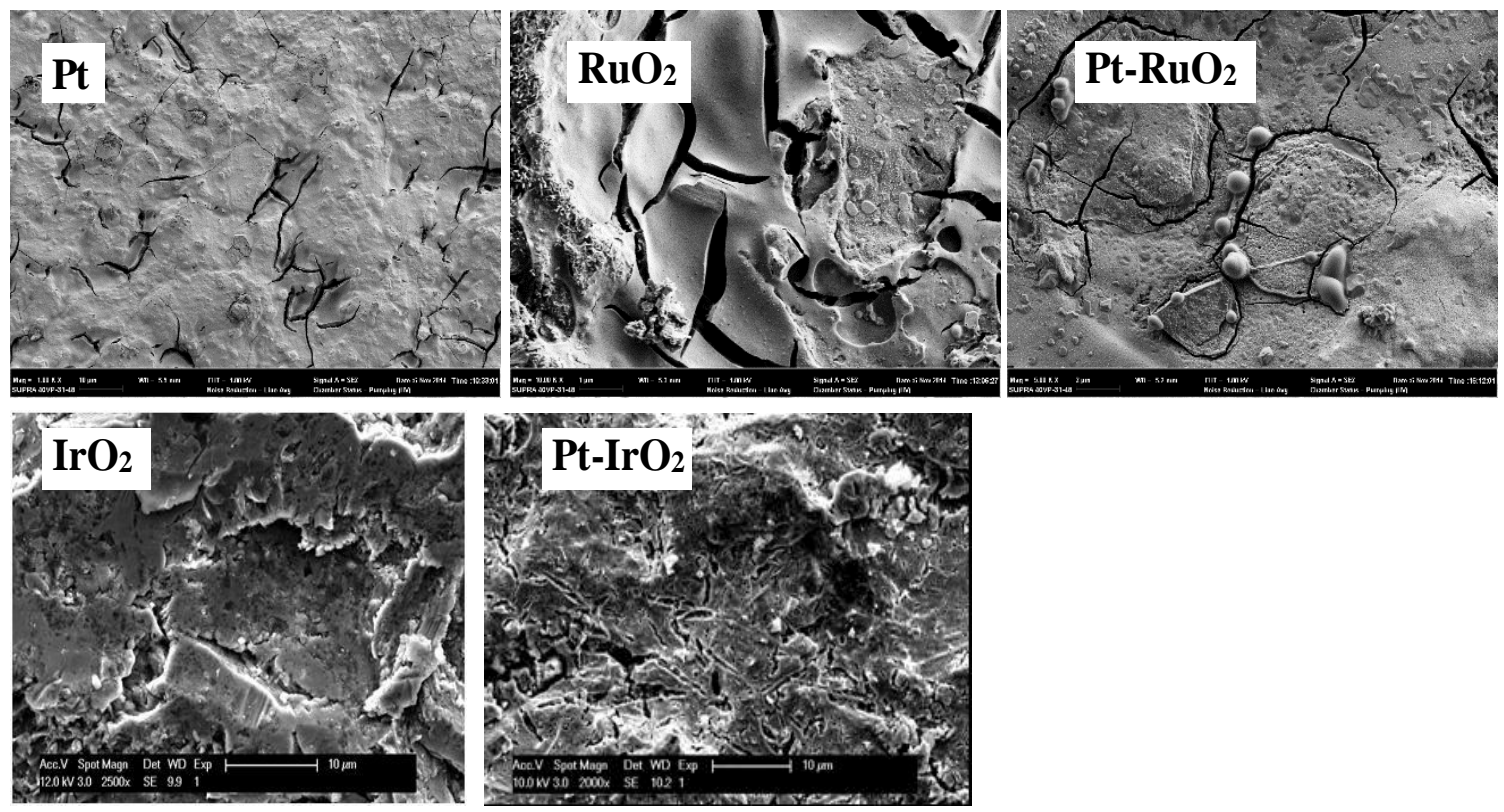

Figure 1: Appearance of the surface of prepared electrodes. 

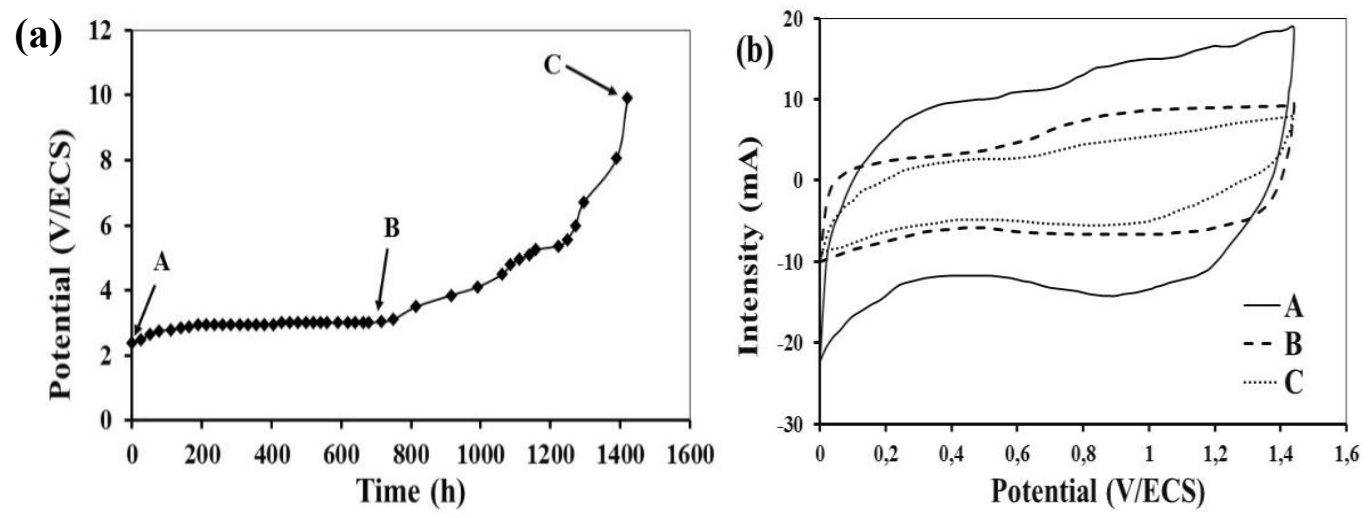

Figure 2: (a) Potential evolution against the time in $\mathrm{H}_{2} \mathrm{SO}_{4} 9 \mathrm{~N}$ with anode: $\mathrm{IrO}_{2}$ and cathode: $\mathrm{Pt}$; (b) Voltammograms in $1 \mathrm{M} \mathrm{HClO}_{4}$ at points $\mathrm{A}, \mathrm{B}$ and $\mathrm{C}$; $\mathrm{WE}: \mathrm{IrO}_{2}, \mathrm{CE}$ : Pt wire
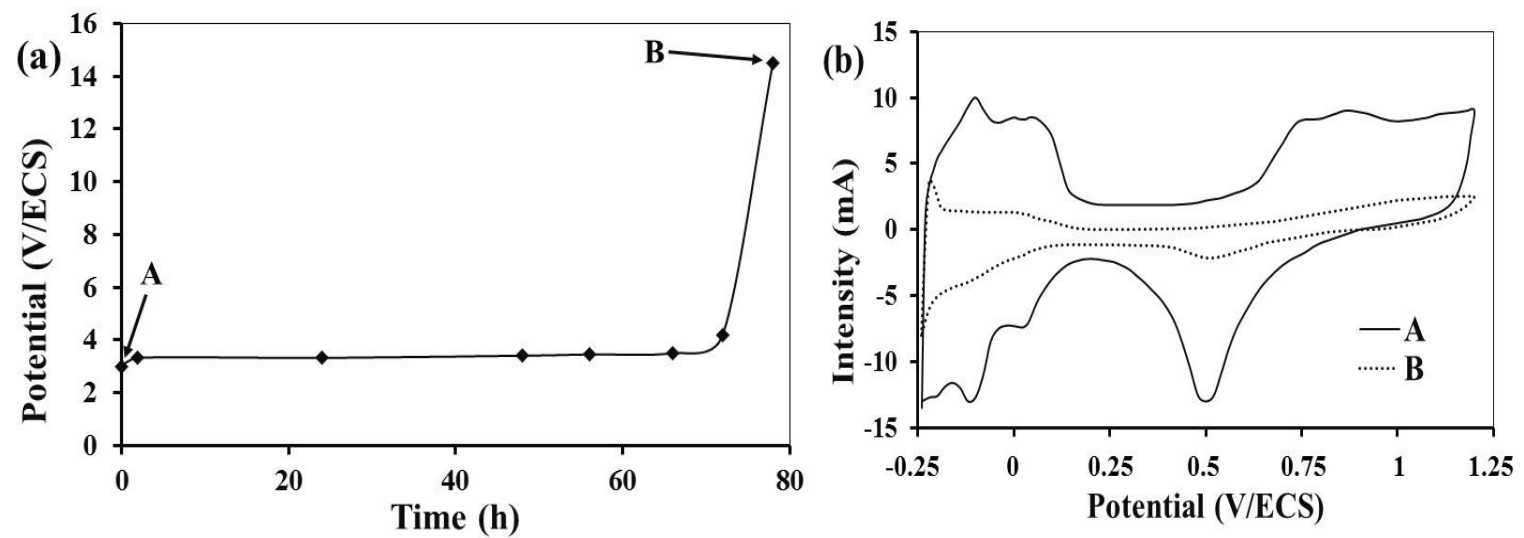

Figure 3: (a) Potential against the time in $\mathrm{H}_{2} \mathrm{SO}_{4} 9 \mathrm{~N}$ with anode: prepared $\mathrm{Pt}$ and cathode: $\mathrm{Pt}$ wire; (b) Voltammogram in $1 \mathrm{M} \mathrm{HClO}_{4}$ at points $\mathrm{A}$ and B; WE: prepared Pt, CE: Pt wire.
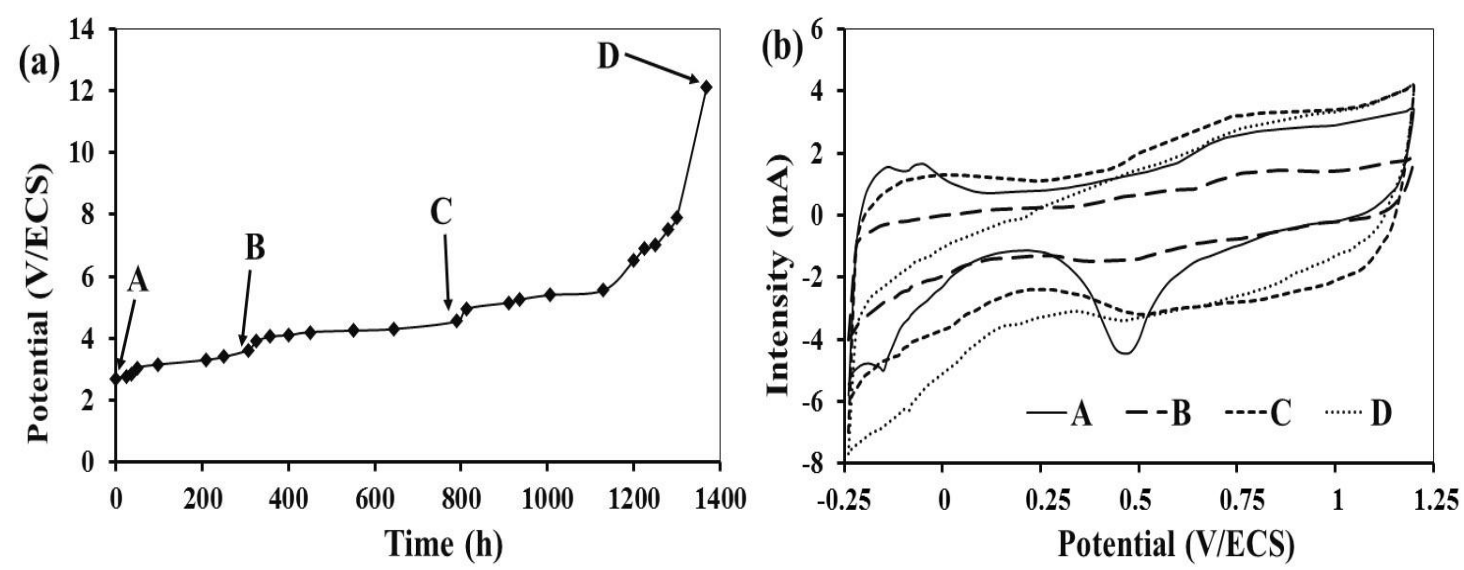

Figure 4: (a) Potential evolution versus time in $\mathrm{H}_{2} \mathrm{SO}_{4} 9 \mathrm{~N}$ with anode: $\mathrm{Pt}-\mathrm{IrO}_{2}$ and cathode: $\mathrm{Pt}$ wire; (b) Voltammograms in $1 \mathrm{M} \mathrm{HClO}_{4}$ at points A, B, C and D, WE: Pt-IrO 2 , CE: Pt wire. 

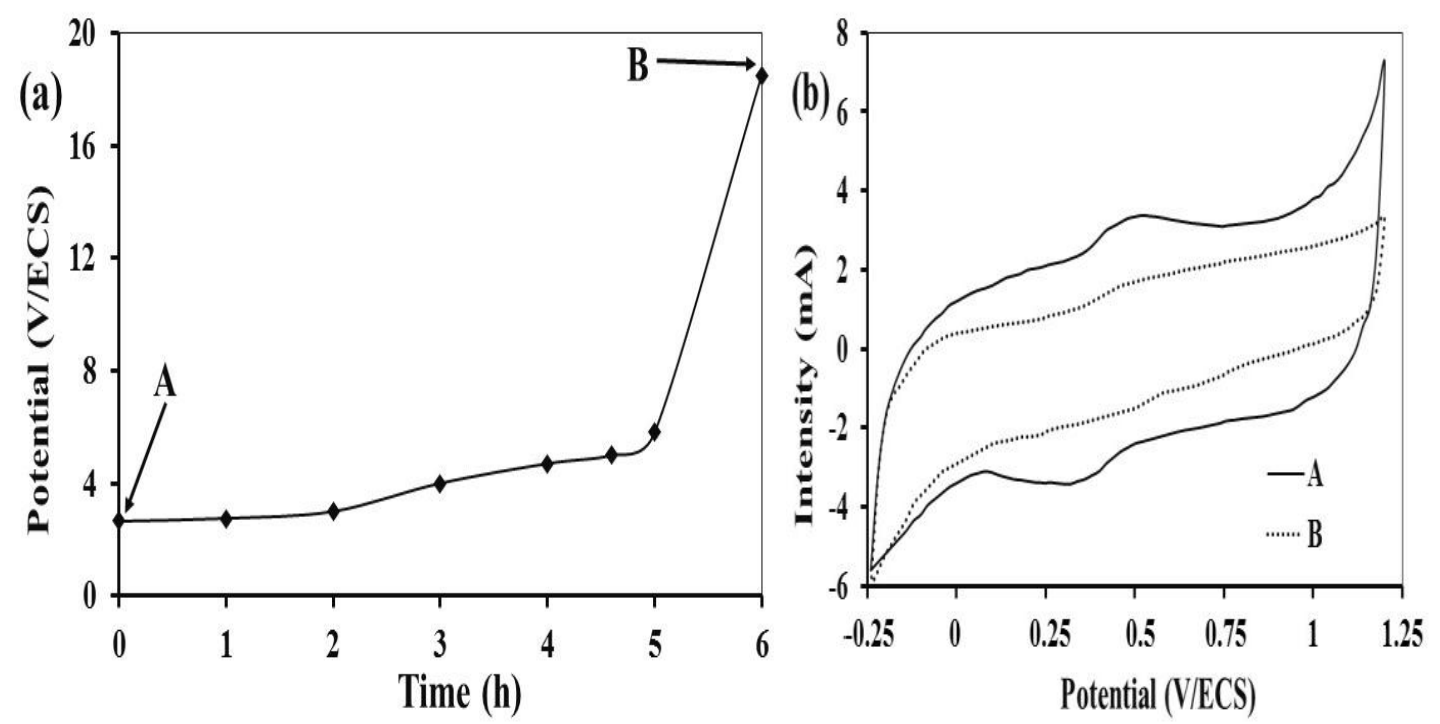

Figure 5: (a) Potential evolution against the time in $\mathrm{H}_{2} \mathrm{SO}_{4} 9 \mathrm{~N}$ with anode: $\mathrm{RuO}_{2}$ and cathode: $\mathrm{Pt}$ wire; (b) Voltammogram in $1 \mathrm{M} \mathrm{HClO}_{4}$ at points A and B; WE: $\mathrm{RuO}_{2}, \mathrm{CE}$ : Pt wire.
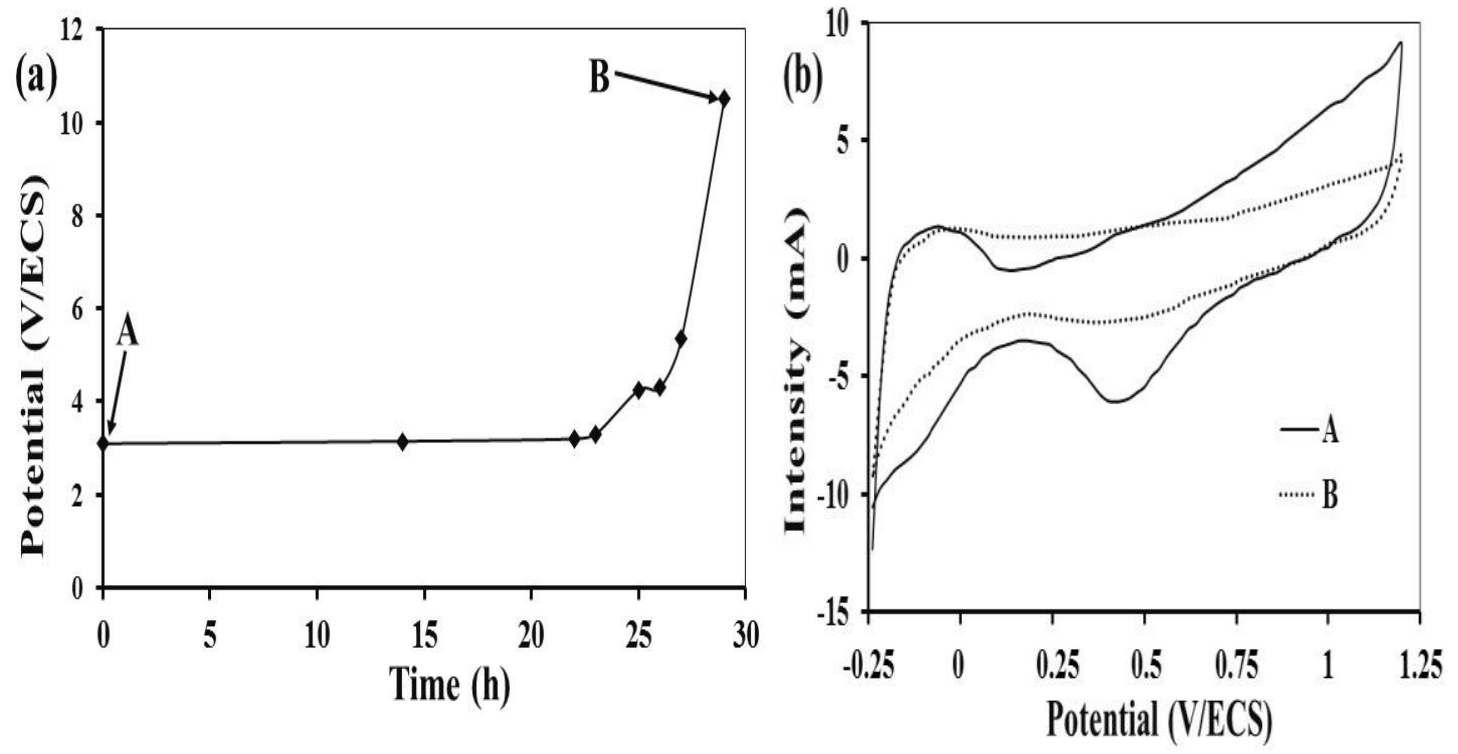

Figure 6: (a) Potential evolution against the time in $\mathrm{H}_{2} \mathrm{SO}_{4} 9 \mathrm{~N}$ with anode: $\mathrm{Pt}-\mathrm{RuO}_{2}$ and cathode: Pt wire; (b) Voltammogram in $1 \mathrm{M} \mathrm{HClO}_{4}$ at points A and B; WE: $\mathrm{Pt}-\mathrm{RuO}_{2}$, CE: Pt wire. 


\section{DISCUSSION}

Pt electrode remains by far an ideal choice of anode for the electrochemical processes application. The improvement of its electrocatalytic properties by the addition of metal oxides $\left(\mathrm{RuO}_{2}\right.$ and $\left.\mathrm{IrO}_{2}\right)$ contributes to extending its field of application. However, the coupling of these oxides to Pt could have an impact on its lifetime, that is to say on its time of use. For this, we have prepared, subjected different electrodes $\left(\mathrm{Pt}, \mathrm{IrO}_{2}, \mathrm{RuO}_{2}, \mathrm{Pt}-\mathrm{IrO}_{2}\right.$ and $\mathrm{Pt}-\mathrm{RuO}_{2}$ ) to drastic conditions (under current density of $410 \mathrm{~mA} / \mathrm{cm}^{2}$ and in a solution of $\mathrm{H}_{2} \mathrm{SO}_{4} 9 \mathrm{~N}$ ), and finally followed the evolution of the potential across these over time.

The results of the physical characterization of the prepared electrodes revealed the presence of the various deposits on the titanium plates. These deposits suggest a rough and porous structure of our electrodes. These results are in agreement with the studies carried out by literature (Kambire et al., 2015b; Berté et al., 2016). The cracks observed on the electrodes surface occur during the cooling of the deposit due to the thermal shock to which these deposits are subjected during their removal from the oven. On the iridium oxide electrode, the peaks observed at $0.7 \mathrm{~V}$ and $1 \mathrm{~V}$ /SCE potentials on the voltammetric curve characterize the electrochemical behavior of the $\mathrm{IrO}_{2}$ electrode (Felix et al., 2019; Kariman et al., 2019). These peaks observed at these potentials correspond to the redox transitions of $\operatorname{Ir}(\mathrm{III}) / \operatorname{Ir}(\mathrm{IV})$ and $\operatorname{Ir}(\mathrm{IV}) / \operatorname{Ir}(\mathrm{VI})$ (Ouattara et al., 2009; Kapałka et al., 2009). For potentials less than $0 \mathrm{~V} / \mathrm{SCE}$, the capacitive load decreases, which indicates a low conductivity of the electrode in this region. There is an absence of surface redox process in this domain. This could be due to a strong resistance of the electrode in the cathode domain (Panic et al., 2010). After $678 \mathrm{~h}$ of polarization, an increase in the voltammetric charge is observed. This observation reflects the electrode activation by hydration of the deposit (Ouattara et al., 2009). The loss of the electrochemical activity of the $\mathrm{IrO}_{2}$ electrode, after $1421 \mathrm{~h}$, is characterized by a progressive reduction in the voltammetric charge which becomes lower than that of the freshly prepared electrode. The strong chemical affinity that titanium has for oxygen, would favor a good adhesion of $\mathrm{IrO}_{2}$ deposit on titanium, by the formation of chemical bond. Thus, the deactivation of the iridium oxide electrode would be due to the dissolution of the deposit on titanium (Tan et al., 2019).

The electrochemical characterization of the prepared platinum electrode made it possible to observe different peaks such as: the peaks of hydrogen adsorption and desorption (0.2 to $0.1 \mathrm{~V} / \mathrm{SCE}$ ), the wave corresponding to the formation of an oxide layer on the $\mathrm{Pt}$ electrode surface ( 0.4 to $1.2 \mathrm{~V} / \mathrm{SCE})$ and the reduction peak of this oxide to $0.45 \mathrm{~V} / \mathrm{SCE}$. A domain where the current is almost zero was also observed from 0.1 to $0.35 \mathrm{~V} / \mathrm{SCE}$. This is the double layer domain. This voltammogram is in agreement with data from the literature (Pohan et al., 2013a; Pohan et al., 2013b; Kambire et al., 2015b; Kambire et al., 2015c). The Pt electrode deactivation during the lifetime study (after 72 hours of polarization) would be due to the platinum deposit detachment from the titanium support. This detachment would be caused by a lack of adhesion which originates from the nature of the "deposit-titanium" interface. In fact, the "deposit-titanium" interface is characterized by a mechanical attachment of the platinum layer to the rough surface of the titanium. There is therefore no real chemical bond.

On the $\mathrm{Pt}-\mathrm{IrO}_{2}$ electrode, the voltammetric curves produced testify to the $\mathrm{Pt}$ presence. Indeed, the Pt oxide reduction peak is clearly visible at around $0.5 \mathrm{~V} / \mathrm{SCE}$ on freshly prepared $\mathrm{Pt}-\mathrm{IrO}_{2}$. We also have hydrogen adsorption and desorption at cathodic potentials. This platinum reduction peak almost disappears and the voltammetric charges of hydrogen adsorption and desorption 
decrease sharply, after 306 hours of polarization. This suggests a possible departure of Pt from the electrode surface. Thus, from 0 to 306 hours of polarization, the $\mathrm{Pt}-\mathrm{IrO}_{2}$ electrode would be stable in the experimental environment. By comparing these results with those obtained on the pure $\mathrm{Pt}$ electrode $(\mathrm{Pt}$ deposited directly on the titanium), one can then think that in the case of the coupled electrode $\left(\mathrm{Pt}-\mathrm{IrO}_{2}\right)$, the platinum is not in contact direct with titanium but with iridium oxide. This is probably what justifies the relative stability of $\mathrm{Pt}$ in $\mathrm{Pt}-\mathrm{IrO}_{2}$ deposited on titanium.

From the lifetime study of this first group of electrodes $\left(\mathrm{IrO}_{2}, \mathrm{Pt}\right.$ and $\left.\mathrm{Pt}-\mathrm{IrO}_{2}\right)$, it appears that the pure $\mathrm{IrO}_{2}$ electrode is more stable than that of pure $\mathrm{Pt}$ in very corrosive environment. The coupling $(50 \%$ by mol of each element) of the two electrodes makes it possible to have an electrode having a stability comparable to that of the pure $\mathrm{IrO}_{2}$ electrode. The mixture of $\mathrm{Pt}$ and Ir precursors would allow an electrode whose surface would be composed of a heterogeneous mixture of $\mathrm{Pt}$ and $\mathrm{IrO}_{2}$. Pt deposition on titanium is less stable than on iridium oxide. The deactivation of the $\mathrm{Pt}-\mathrm{IrO}_{2}$ coupled electrode would be due, on the one hand to the detachment of platinum from iridium oxide and on the other hand, to the $\mathrm{IrO}_{2}$ dissolution. The $\mathrm{IrO}_{2}, \mathrm{Pt}$ and $\mathrm{Pt}-\mathrm{IrO}_{2}$ electrodes can be classified in the following increasing order of service life: $\mathrm{Pt}<\mathrm{Pt}-\mathrm{IrO}_{2}<\mathrm{IrO}_{2}$.

On $\mathrm{RuO}_{2}$ electrode, the voltammogram obtained is in agreement with our previous work (Kambire et al., 2015a; Appia et al., 2016). The gradual increase in potential, from 2 to 5 hours, could be due to hydration of the deposit as observed in the case of the $\mathrm{IrO}_{2}$ electrode. $\mathrm{RuO}_{2}$ deposit would begin to dissolve from the support just after $5 \mathrm{~h}$ of polarization. This dissolution would lead to a reduction in voltammetric charges and a sudden increase in potential.

On $\mathrm{Pt}-\mathrm{RuO}_{2}$ electrode, the potential remains constant from 0 to 23 hours of polarization. There would be no departure from the electrode (neither Pt nor $\mathrm{RuO}_{2}$ ). After $23 \mathrm{~h}$ of polarization, the potential increases slowly, this could be due to the departure of one of the mixture $\left(\mathrm{Pt}-\mathrm{RuO}_{2}, 50 \%\right.$ by mol of each element) constituents, which would be Pt, due to the drop in intensity of the platinum oxide reduction peak observed on the voltammogram of Figure $6 \mathrm{~b}$. The constant potential observed from 25 to 26 hours could justify the mere presence of $\mathrm{RuO}_{2}$ on the titanium support.

The lifetime study of the electrodes $\left(\mathrm{RuO}_{2}\right.$ and $\left.\mathrm{Pt}-\mathrm{RuO}_{2}\right)$ shows that pure $\mathrm{RuO}_{2}$ is not stable in very corrosive medium. The addition of this oxide to $\mathrm{Pt}$ (50\% in mol of each element), leads to an electrode less stable in very corrosive medium than the pure $\mathrm{Pt}$ electrode. Indeed, under the same conditions of the experiment, we are witnessing the $\mathrm{Pt}$ departure from the support surface after $72 \mathrm{~h}$ of polarization. The couple $\mathrm{Pt}$ and $\mathrm{RuO}_{2}$ leads to an electrode more stable than pure $\mathrm{RuO}_{2}$ and less stable than pure Pt. $\mathrm{RuO}_{2}$ electrode deactivation is mainly due to the dissolution and $\mathrm{RuO}_{2}$ detachment deposit from the titanium substrate. Indeed, although the $\mathrm{RuO}_{2}$ preparation temperature $\left(400{ }^{\circ} \mathrm{C}\right)$ makes it possible to obtain an electrode having a significant electrochemical activity (Zhang et al., 2012), in an acid medium we are witnessing the $\mathrm{RuO}_{2}$ dissolution (Tan et al., 2019). In an acidic environment, $\mathrm{RuO}_{2}$ acts as a proton capacitor, thus facilitating the penetration of the corrosive electrolyte through the microcracks of the electrode and leading to the formation of an insulating film of $\mathrm{TiO}_{2}$. The formation of this $\mathrm{TiO}_{2}$ film considerably reduces the adhesion of the deposit and causes its detachment. Thus, the synergy of these two processes, namely the dissolution and the formation of the $\mathrm{TiO}_{2}$ insulating film could explain the short lifetime of $\mathrm{RuO}_{2}$ and $\mathrm{Pt}-\mathrm{RuO}_{2}$ in very corrosive medium. The $\mathrm{RuO}_{2}, \mathrm{Pt}$ and $\mathrm{Pt}-\mathrm{RuO}_{2}$ electrodes can be classified according to the following increasing lifetime order: $\mathrm{RuO}_{2}<$ Pt-RuO $2<$ Pt. 


\section{Conclusion}

It appears from these studies that the deposits of $\mathrm{Pt}, \mathrm{RuO}_{2}, \mathrm{Pt}-\mathrm{RuO}_{2}, \mathrm{IrO}_{2}$ and $\mathrm{Pt}-\mathrm{IrO}_{2}$ are indeed present on the titanium support. This study has shown that during the use of the electrodes, the voltammetric charge of them decreases progressively. This indicates a loss of the electrode electrochemical activity. With the $\mathrm{IrO}_{2}$ and $\mathrm{RuO}_{2}$ electrodes the deactivation would be due to the deposits dissolution on the titanium. As for the Pt electrode, deactivation would be due to the Pt deposit detachment from the titanium support. The deactivation of the $\mathrm{Pt}-\mathrm{IrO}_{2}$ and $\mathrm{Pt}-\mathrm{RuO}_{2}$ coupled electrode would be due, on the one hand, to the Pt detachment from metal oxides $\left(\mathrm{IrO}_{2}\right.$ and $\left.\mathrm{RuO}_{2}\right)$ and, on the other hand, to the dissolution of metal oxides. The study showed that the lifetimes of $\mathrm{Pt}$, $\mathrm{RuO}_{2}, \mathrm{Pt}-\mathrm{RuO}_{2}, \mathrm{IrO}_{2}$ and $\mathrm{Pt}-\mathrm{IrO}_{2}$ electrodes are 72, 6, 29, 1421 and 1369 hours, respectively. This shows that the coupling of $\mathrm{Pt}$ with $\mathrm{RuO}_{2}$ reduces the lifetime of the electrode from 72 to 29 hours, on the other hand the coupling of $\mathrm{Pt}$ with $\mathrm{IrO}_{2}$ makes it possible to increase its lifetime from 72 to 1369 hours.

\section{COMPETING INTERESTS}

The authors declare that they have no competing interests.

\section{AUTHORS' CONTRIBUTIONS}

The authors LAGP, OK and MB contributed to the laboratory experiments, to the introduction and abstract writing, the results and discussion presentation, and the conclusion. LO contributed to the manuscript total revision.

\section{ACKNOWLEDGEMENTS}

This work was financed by the secretary executive of France.

\section{REFERENCES}

An H, Cui H, Zhang W, Zhai J, Qian Y, Xie X, $\mathrm{Li}$ Q. 2012. Fabrication and electrochemical treatment application of a microstructured

$\mathrm{TiO}_{2}-\mathrm{NTs} / \mathrm{Sb}-$

$\mathrm{SnO}_{2} / \mathrm{PbO}_{2}$ anode in the degradation of C.I. Reactive Blue 194 (RB 194). Chemical Engineering Journal, 209: 8693.

DOI:

https://doi.org/10.1016/j.cej.2012.07.089

Appia FTA, Gnamba CQ-M, Kambiré O, Berté

M, Sadia SP, Sanogo I, Ouattara L. 2016.

Electrochemical Oxidation of

Amoxicillin in Its Commercial

Formulation on Thermally Prepared $\mathrm{RuO}_{2} /$ Ti. J. Electrochem. Sci. Technol, 7(1): $\quad$ 82-89. DOI: http://dx.doi.org/10.5229/JECST.2016.7. 1.82

Berté M, Appia FTA, Sanogo I, Ouattara L. 2016. Electrochemical Oxidation of the Paracetamol in its Commercial Formulation on Platinum and Ruthenium Dioxide Electrodes. Int. J. Electrochem. Sci., 11: 7736-7749. DOI: http://dx.doi.org/10.20964/2016.09.44

Coulibaly NH, Brou YS, Diomande GD, Creus J, Trokourey A. 2018. Nicotinic acid as green inhibitor for copper corrosion in 3.5 wt $\% \mathrm{NaCl}$ solution: experimental and quantum chemical calculations. Int. J. Biol. Chem. Sci., 12(2): 1008-1027. DOI: https://dx.doi.org/10.4314/ijbcs.v12i2.30

Datché MT, Mou AAS, Trokourey A. 2014. Electrochemical determination of mercury (ii) concentrations with carbon paste electrode modified in wastewater. Rev. Ivoir. Sci. Technol., 24: 57- 68.

Felix C, Bladergroen BJ, Linkov V, Pollet BG, Pasupathi S. 2019. Ex-Situ Electrochemical Characterization of $\mathrm{IrO}_{2}$ Synthesized by a Modified Adams Fusion Method for the Oxygen Evolution Reaction. Catalysts, 318(9): 1-16. DO: https://doi.org/10.3390/catal9040318

Gong N, Zhao Z. 2019. Efficient supported PtSn catalyst on carambola-like alumina for direct dehydrogenation of propane to propene. Molecular Catalysis, 477: 
110543.

DOI:

10.1016/j.mcat.2019.110543

Huguenot DE, Mousset ED, Hullebusch V, Oturan MA. 2015. Combination of surfactant enhanced soil washing and electro-Fenton process for the treatment of soils contaminated by petroleum hydrocarbons. Journal of Environmental Management, 153: 40-47. DOI: http://dx.doi.org/10.1016/j.jenvman.2015 .01 .037

Kambire O, Appia FT A, Ouattara L. 2015a, Oxygen and chlorine evolution on ruthenium dioxide modified by platinum in acid solutions. Rev. Ivoir. Sci. Technol., 25: $21-33$.

Kambire O, Pohan LAG, Appia FTA, Ouattara L. 2015b. Anodic Oxidation of Chlorides on Platinum Modified by Metallic Oxides. Int. J. Pure Appl. Sci. Technol., 27(1): 27-43.

Kambire O, Pohan LAG, Appia FTA, Gnamba CQ-M, Kondro KH, Ouattara L. 2015c. Influence of various metallic oxides on the kinetic of the oxygen evolution reaction on platinum electrodes. $J$. Electrochem. Sci. Eng. 5(2): 79-91. DOI: http://dx.doi.org/10.5599/jese. 157

Kapałka A, Fierro S, Frontistis Z, Katsaounis A, Frey O, Koudelka M, Comninellis C, Udert KM. 2009. Electrochemical behaviour of ammonia $\left(\mathrm{NH}^{+}{ }_{4}=\mathrm{NH}_{3}\right)$ on electrochemically grown anodic iridium oxide film (AIROF) electrode. Electrochemistry Communications, 11: 1590-1592. DOI: 10.1016/j.elecom.2009.06.003

Kariman A, Marshall AT. 2019. Improving the Stability of DSA Electrodes by the Addition of $\mathrm{TiO}_{2}$ Nanoparticles, Journal of The Electrochemical Society, 166 (8): E248-E251. DOI: http://dx.doi.org/ 10.1149/2.0761908jes

Khalifeh-Soltani MS, Shams E, Sharifi E. 2020. Pt-Ru nanoparticles anchored on poly(brilliantcresyl blue) as a new polymeric support:Application as an efficient electrocatalyst inmethanol oxidation reaction. International Journal of Hydrogen Energy, 45: 849-860. DOI: http://dx.doi.org/10.1016/j.ijhydene.2019 .10 .071

Klein J, Argast F, Engstfeld AK, Brimaud S, Behm RJ. 2019. Electro-oxidation of methanol on $\mathrm{Ru}$-core Pt-shell type model electrodes, Electrochimica Acta, 311: 244-254.

DOI:

http://dx.doi.org/10.1016/j.electacta.201 9.04.081

Liu J, Tang Q, He B. 2014. Platinum-free binary $\mathrm{Fe}-\mathrm{Co}$ nanofiber alloy counter electrodes for dye-sensitized solar cells. Journal of Power Sources, 268: 56-62. DOI: http://dx.doi.org/10.1002/anie.20140698 2.

Maman MA, Sawadogo J, Bambara D, Bougouma M, Legma JB. 2017. Analyses électrochimiques des eaux de pluie provoquées : cas du Burkina Faso. Int. J. Biol. Chem. Sci., 11(5): 2521-2536. DOI: https://dx.doi.org/10.4314/ijbcs.v11i5.45

Oller I, Malato S, Sánchez-Pérez JA. 2011. Combination of Advanced Oxidation Processes and biological treatments for wastewater decontamination. Science of the Total Environment, 409: 4141-4166. DOI:

http://dx.doi.org/10.1016/j.scitotenv.201 0.08 .061

Olvera-Vargas H, Oturan N, Oturan MA, Brillas E. 2015. Electro-Fenton and solar photoelectro-Fenton treatments of the pharmaceutical ranitidine in pre-pilot flow plant scale. Separation and Purification Technology, 146: 127-135. DOI:

https://doi.org/10.1016/j.seppur.2015.03. 046

Ouattara L, Fierro S, Frey O, Koudelka M, Comninellis C. 2009. Electrochemical comparison of $\mathrm{IrO}_{2}$ prepared by anodic 
oxidation of pure iridium and $\mathrm{IrO}_{2}$ prepared by thermal decomposition of $\mathrm{H}_{2} \mathrm{IrCl}_{6}$ precursor solution. $J \mathrm{Appl}$ Electrochem, 39: 1361-1367. DOI: http://dx.doi.org/10.1007/s10800-0099809-2

Ouedraogo ER, Dibala CI, Konate K, Diarra J, Dicko MH. 2020. Etude du phénomène de remontée de boue sur le décanteur lamellaire de la station de traitement d'eau de Paspanga au Burkina Faso. Int. J. Biol. Chem. Sci., 14(2): 364-37. DOI: https://dx.doi.org/10.4314/ijbcs.v14i2.5

Panic VV, Dekanski AB, Mitric M, Milonjic SK, Miskovic-Stankovic VB. 2010. The effect of the addition of colloidal iridium oxide into sol-gel obtained titanium and ruthenium oxide coatings on titanium on their electrochemical properties. Phys Chem Chem Phys, 12(27): 7521-8. DOI: http://dx.doi.org/ 10.1039/b921582d.

Pohan ALG, Ouattara L, Kondro KH, Kambiré O, Trokourey A. 2013a. Electrochemical Treatment of the Wastewaters of Abidjan on Thermally Prepared Platinum Modified Metal Oxides Electrodes. European Journal of Scientific Research, Série 1, 94: 96-108.

Pohan LAG, Kondro KH, Trokourey A, Ouattara L. 2013b. Influence of Chlorides on the Electrochemical Oxidation of Formic Acid on Thermally Prepared Platinum Electrodes. Int. J. Pure Appl. Sci. Technol., 14(1): 33-43.

Sawadogo R, Guiguemde I, Diendere F, Diarra J, Bary A. 2012. Caractérisation physicochimique des eaux résiduaires de tannerie: cas de l'usine TAN ALIZ à
Ouagadougou / Burkina Faso. Int. J. Biol. Chem. Sci., 6(6): 7087-7095. DOI: http://dx.doi.org/10.4314/ijbcs.v6i6.43.

Tan X, Shen J, Semagina N, Secanell M. 2019. Decoupling structure-sensitive deactivation mechanisms of $\mathrm{Ir} / \mathrm{IrOx}$ electrocatalysts toward oxygen evolution reaction. Journal of Catalysis, 371: 5770.

DOI: https://doi.org/10.1016/j.jcat.2019.01.01 8

Yi L, Song Y, Yi W, Wang X, Wang H, He P, Hu B. 2011. Carbon supported Pt hollow nanospheres as anode catalysts for direct borohydride-hydrogen peroxide fuel cells. International Journal of Hydrogen Energy, 36: 11512-11518. DOI: https://doi.org/10.1016/j.ijhydene.2011.0 4.077

Zhang Y, Yue L, Teng K, Yuan S, Ma H. 2012. Synthesis and Characterization of $\mathrm{RuO}_{2}$ Anode Materials with Large Surface Areas for Oxygen Evolution Reaction. Journal of New Materials for Electrochemical Systems, 15: 271-276. DOI: http://dx.doi.org/10.14447/jnmes.v15i4.4 5

Zhou M, Sarkka H, Sillanpaa M. 2011. A comparative experimental study on methyl orange degradation by electrochemical oxidation on BDD and MMO electrodes. Separation and Purification Technology, 78: 290-297. DOI: http://dx.doi.org/10.1016/j.seppur.2011.0 2.013 